\title{
Laura Álvarez López* \\ The dialect of São João da Chapada: Possible remains of a mining language in Minas Gerais, Brazil
}

https://doi.org/10.1515/ijsl-2019-2032

\begin{abstract}
This article focuses on the analysis of a specific vocabulary, possibly the remains of a mining language spoken by descendants of Africans. It analyzes 149 lexical items that were registered in the 1920s in a rural region of Minas Gerais, near the city of Diamantina. Based on earlier historical and linguistic studies, as well as on dictionaries of relevant African languages, the lexical study aims to analyze 149 words and expressions in order to verify the etymologies, and determine whether they fit the demographic data available on the origins of the slave population in this area. The second aim is to analyze the distribution of the lexical items in different semantic domains and word classes and compare the observed tendencies, as well as other linguistic characteristics and social functions, with other mining languages and/or similar Afro-Brazilian and Afro-European varieties. The results indicate that Umbundu maintained a high status in the area, and that this variety was not limited to mining activities, but was probably used in everyday life as a secret code that was part of the strategies of resistance among slaves.
\end{abstract}

Keywords: Portuguese, African languages, lexicon, mining, Brazil, Minas Gerais

\section{Introduction}

At the end of the seventeenth century, alluvial gold was discovered in a geographical region that subsequently became the Brazilian state of Minas Gerais, a state that got its name from the general mines exploited within its territory. According to Boxer (1964: 163), "[t]he gold of Minas Gerais thus played a far from insignificant role on the eighteenth-century world stage”. Around 1730, diamonds were found in this area, and thus mining was favored at the expense of agriculture (Boxer 1964: 188). At this stage, the city of Villa Rica de Ouro Preto, or "Rich Town of Black Gold", which had been chosen as the capital of the captaincy of Minas Gerais, was referred to as "golden Potosí" (cf. "Cerro

*Corresponding author: Laura Álvarez López, Stockholm University, Stockholm, Sweden, E-mail: laura.alvarez@su.se

Ә Open Access. ( 2019 Álvarez López, published by De Gruyter. (c) BY This work is licensed under the Creative Commons Attribution 4.0 Public License. 
Rico”, Muysken this volume). By then, Brazilian gold and diamonds had been used to repay Portugal's debts to England, and Brazil had become the world's largest producer of gold, with Minas Gerais being its fastest-growing region (Skidmore 1999: 21).

Most of the hard mining work in the colony was done by enslaved Africans who had been brought either directly from Africa or from elsewhere in Brazil. In this sociohistorical setting, Africans from "Whydah [Ouidah in Benin, West Africa] were believed to have a peculiar gift for discovering new gold-bearing deposits", and living with a "Mina" woman was supposed to bring good luck in mining activities (Boxer 1964: 165). ${ }^{1}$ Apart from working in the mines, captives built new roads used for the transportation of extracted minerals. Slaveholders also made enslaved Africans and their descendants perform other types of forced labor, such as agriculture and domestic work.

This was a multilingual and multicultural setting with a constant introduction of newcomers from Africa when, in 1757, a decree of the Marquis of Pombal prohibited the use of languages other than Portuguese in Brazil (Álvarez López 2004: 68). In spite of this prohibition, Afro-Brazilian linguistic varieties and cultural practices emerged in more or less isolated and marginalized rural communities around the country (see, for example, Álvarez López and Jon-And 2017; Lucchesi et al. 2009).

This article focuses on the analysis of a specific vocabulary, possibly the remains of a mining language spoken by descendants of Africans, that was registered in the 1920s in a rural region of Minas Gerais, near the city of Diamantina. Based on earlier historical and linguistic studies, as well as on dictionaries of relevant African languages, the lexical study aims to analyze 149 words and expressions that have been registered, verify the etymologies of these as proposed by Machado Filho (1943) and Simões (2014), and determine whether they fit the demographic data available on the origins of the slave population in this area. The second aim is to analyze the distribution of the lexical items in different semantic domains and word classes and compare the observed tendencies as well as other linguistic characteristics and social functions with other mining languages such as Fanakalo (see Mesthrie this volume) and/or similar Afro-European and Afro-Brazilian varieties (see Álvarez López and Jon-And 2017; Petter 2013; Bartens and Baker 2012; Byrd 2012; Querioz 1998).

\footnotetext{
1 "Mina" refers to the region in West Africa that the Portuguese called Costa da Mina, meaning the 'Coast of the Mine', also known as the Gold Coast: "what the English termed respectively the Ivory, Gold and Slave Coasts, from Cape Palmas to the Cameroons” (Boxer 1964: 175; Álvarez López 2015).
} 


\section{Primary and secondary sources for the study of the remains of mining languages in Brazil}

There are, to the best of my knowledge, only two adequate sources for the study of mining languages in Brazil from a historical perspective. Both are based on empirical linguistic data gathered in Afro-Brazilian communities in Minas Gerais in the early eighteenth and nineteenth centuries.

In the eighteenth century, António da Costa Peixoto documented an "African language" in Minas Gerais in two manuscript manuals of conversation in the language spoken by African gold mining slaves around Ouro Preto: Alguns apontamentos da lingoa Minna com as palavras portuguesas correspondents [Some notes on the Minna language with the corresponding Portuguese words, 1731] and Obra nova de Lingoa Geral de mina, traduzida, áo nosso Igdioma por Antonio da Costa Peixoto [New work on the General language of Mina, translated to our language by Antonio da Costa Peixoto]. According to more recent work by Castro (2002), the documented variety most probably emerged among speakers of Gbe languages and their descendants.

Peixoto was born in Portugal, but lived in Minas Gerais, where he documented the language with the purpose of helping slave owners avoid "insults", "theft", and "death", among other dreadful things that he mentions being possible in his prologue to the reader (Peixoto 1944: 13). This variety reminds one of Fanakalo (see Mesthrie this volume) in the sense that it was registered by a European who can be said to represent the employers and was intended for use as a lingua franca in a multilingual context where mining work was performed by non-Europeans. Peixoto's manuscripts were published in 1944; however, more recent research in the region has not been able to identify any remains of this Gbe-based variety (Simões 2014).

In 1929, almost 200 years after Peixoto's fieldwork, Aires da Mata Machado Filho collected linguistic data in São João da Chapada, ${ }^{2}$ in the municipality of Diamantina, Minas Gerais, where small-scale mining (mainly of diamonds) was practiced, and where mining songs were part of the cultural heritage. Machado Filho had been born in the district in 1909. His work, O Negro e o Garimpo em Minas Gerais (Machado Filho 1943), first published in the journal Revista do Arquivo Municipal de São Paulo in 1939, was later published as a book by Livraria José Olympio in 1943 (Giovanni Junior 2014: 4). The book focuses on mining communities in the district and includes 65 local songs and a glossary with a total of 153 lexical entries, many of which were extracted from the songs

2 Situated approximately 30 kilometers from the city of Diamantina (Simões 2014: 31). 
and classified as being specific to the "dialect of São João da Chapada" (Machado Filho 1943: 117-133). Although the author had studied philology, the glossary only provides examples of use for a limited number of lexical items, as in the following example:

AIUCA, adj. - Muito, muita. O superlativo é formado com a duplicação do vocábulo. Curima aiuca-aiuca; omenhá aiuca-aiuca: muitíssimo serviço, água demasiada.

[AIUCA, adj. - Much, many. The superlative is formed by a duplication of the word. Curima aiuca-aiuca; omenhá aiuca-aiuca: very much work, too much water.] (My translation.)

Additionally, the author discusses the social functions and meanings of the mining songs that he collected (Machado Filho 1943: 61-112). Nascimento, who conducted research in the same region as Machado Filho, but in 2000 and 2001, found two brothers who still remembered 14 of these songs (Nascimento 2003). ${ }^{3}$ The songs were called vissungos, an African-derived term first registered by Machado Filho in Brazil (Andrarde 2012: 337), and had specific functions for the miners.

Furthermore, the author affirms that there was a Bantu-based creole language in São João da Chapada, and that most miners understood some of the words in the vissungos: "[t]he Sanjoanense creole dialect has not disappeared completely. In isolated alluvial gold deposits, groups of Blacks speak and sing in the language of their ancestors. And, apparently, until recently, it was largely employed in the studied locality" (Machado Filho 1943: 114-116, my translation).

\section{Methodology for the study}

\subsection{Data selection}

The lexical database in this study is based on $149^{4}$ different words or expressions presented in the "Vocabulary for the Creole of São João" (Machado Filho

3 A documentary of one of the brothers and the cultural practice of singing vissungos, Terra Deu, Terra Come, was directed by Rodrigo Siqueira in 2010. See http://terradeuterracome.com. br/ There are also modern recordings of the songs collected by Machado Filho https://www. youtube.com/watch?v=gil3Mw32OnU.

4 The list in the book has 153 entries, but some of them have several words, and others are variants of words (such as anduro/ondara 'fire' and aquenjê/aquenjê verome 'young boy', which in my list have been grouped as one entry). A few words from examples of use given by Machado have been included in my final list (andambí 'woman', cachupá 'do', pipoquê 'beans', ucumbe 'sun'). See Appendix for a list of the 149 words. 
1943: 117-133). The book also includes a second list (Machado Filho 1943: 134138), with words and expressions from other regions of Brazil that were not considered in the present study. Limiting the analysis to the vocabulary from the district of São João da Chapada makes it possible to relate local demographic, historical, and linguistic data to shed light on the origins of the local African components. This limitation is also motivated by the interest in the social functions of this regional lexicon, which can be related to the origins of its population, the sociocultural context, and the mining activities in the area.

The study focuses on the distribution of the lexical items in semantic domains and word classes, as well as on their etymologies. A similar analysis of an Afro-Brazilian variety called Cupópia was performed by Álvarez López and Jon-And (2017), inspired by the methodological approach adopted in the articles included in a volume edited by Bartens and Baker (2012) about transplanted European languages, which present data from 17 creole languages and contact varieties involving European and African languages.

\subsection{Semantic domains}

In order to discuss the classification of this variety as "mining language", the analysis includes a comparison with other mining languages, as well as with various Afro-Brazilian varieties that may share part of their lexicon with this one. This includes the identification of specific words that can be associated to mining activities as opposed to the lexical items identified as part of a basic vocabulary based on Swadesh's (1971) classical list of basic concepts for comparative linguistic studies.

Since Baker (2012: 275-277) acknowledged difficulties classifying lexical items into the 12 semantic fields that he suggested, an alternative classification of 8 semantic domains is proposed. The semantic domains are: universe and creation (animals, nature, etc.), person (people, body, etc.), language and thought (emotions, communication, etc.), social behavior (religion, relationships, etc.), daily life (home, food, etc.), work and occupation (work activities, tools), physical actions (posture, movements, etc.), and states (quantity, quality, time, etc.). These domains are clearly specified with subdomains in Fieldworks Language Explorer software used to organize the lexical database (http://field works.sil.org/flex/). Such classification left no "unclassified" items and makes it possible to compare the results with those of an analysis based on the same methodology regarding another Afro-Brazilian variety (Álvarez López and JonAnd 2017). 


\subsection{Etymologies}

The methodology for the etymological study aims at verifying the etyma proposed by Machado Filho (1943) and Simões (2014), and focuses on the relation between linguistic and demographic data. It also addresses the conclusions about sociocultural context that can be drawn from the analysis of the distribution of the lexicon in different semantic domains and word classes.

Machado Filho (1943) does not systematically mention the origin of the words listed in his study. Simões, who gathered data in the same region in 2011 for his Master's dissertation, compared his findings with those presented in Machado Filho, his primary source. Simões (2014) findings show that most of the words documented by Filho had also been registered in other AfroBrazilian communities and are of Bantu origin. No lexical items on the list could be traced back to West Africa and Peixoto's work. Therefore, Simões (2014) limited his etymological analysis to the use of three dictionaries of Umbundu, three of Kimbundu, and one of Kimbundu and Kikongo, the languages that are usually mentioned as the sources of Bantu-derived lexical items in Brazil.

The contribution of the present etymological analysis will be to increase the number of dictionaries and secondary sources in order to verify the reliability of Machado's work by confirming the existence of the words, to verify their meanings in other sources, and to corroborate the etymologies proposed by both Machado Filho (1943) and Simões (2014). The additional sources for Africanisms in Brazil are Angenot et al. (2013) and Álvarez López (2004). Angenot et al. (2013) is a glossary with 3,704 entries, and it is limited to Bantu-derived words found in 112 different studies. Álvarez López (2004) includes a glossary of approximately 700 African-derived words and expressions, both Bantu and non-Bantu, gathered in the state of Bahia, but is not one of the sources included in Angenot et al. (2013). The additional dictionaries are Bentley (1895, Kikongo), Johnston (1919, comparative Bantu), Laman (1936, Kikongo), and da Matta (1893, Kimbundu). These are early sources for African languages, published at the end of the nineteenth century or the beginning of the twentieth century, which is important, given that we are discussing African-derived words introduced between 1730 and 1930.

Unfortunately, there are still few secondary sources with diachronic data relating to the population of the relevant region around Diamantina; nevertheless, given that Simões (2014) mainly relies on data from the entire region of Minas Gerais, the aim is to add relevant available historical and demographic information from the municipality of Diamantina. 


\subsection{Word classes}

Regarding the analysis of the distribution of the lexicon in word classes, the aim of this aspect of the study is to offer information about the origins of this variety. Earlier studies suggest that nouns are more easily borrowed and exchanged than terms in other word classes, and that they usually predominate among the African-derived words in contact varieties similar to the one in focus (Bartens and Baker 2012). Moreover, the etymologies of lexical items other than nouns can reveal which languages were involved during the period of formation of a linguistic variety, and such results can be related to demographic data from the region. The word classes distinguished in this study are: nouns, verbs, adjective/ adverbs, pronouns, and other (one interjection for which it was impossible to identify the etymon). Some of the words may pertain to more than one word class, for example, in cases in which a word is used both as a noun and as a verb.

We also know that nouns tend to be borrowed particularly when new or unknown objects and concepts need to be named (Thomason and Kaufman 1988: 77). In this case, basic vocabulary should be less likely to be borrowed than more culture-specific African vocabulary or specific words and expressions that may be associated with mining activities.

\section{The vocabulary of the dialect of São João da Chapada}

This section includes an analysis of the lexical items collected in São Jõao da Chapada by Machado Filho. The linguistic data appears to be reliable, and the vocabulary, although obsolescent, seems to have been part of local linguistic practices until the beginning of the twentieth century, as 77\% of all words (114/ 149) have been attested elsewhere (Âlvarez López 2004; Angenot et al. 2013; Castro 2001; Simões 2014, see Appendix for list of words not found in other sources).

During fieldwork in the same area where both Peixoto and Machado Filho collected their data, Simões did not find any of the words registered by Peixoto, but he found people who recognized many of the terms from Machado Filho's glossary. This may be due to demographic changes in Minas Gerais: in the beginning of the eighteenth century, there was a majority of Africans among slaves, and among these the Mina (Gbe speakers) predominated; whereas, in the nineteenth century, there was a majority of Brazilian born descendants of 
Africans among slaves, and among the African born, Bantu speakers dominated (Kikongo, Kimbundu, Umbundu) (Luna 1980).

Before the analysis of the African-derived lexicon, an overview of the 149 lexical items will be presented in the following section.

\subsection{Distribution of words in semantic domains}

Figure 1 shows that $76 \%$ (113/149) of the words belong to the domains that have to do with universe and creation (nature and animals), daily life (home and food), social behavior (social activities and relationships), and work and occupation. This means that this vocabulary is not limited to mining terms.

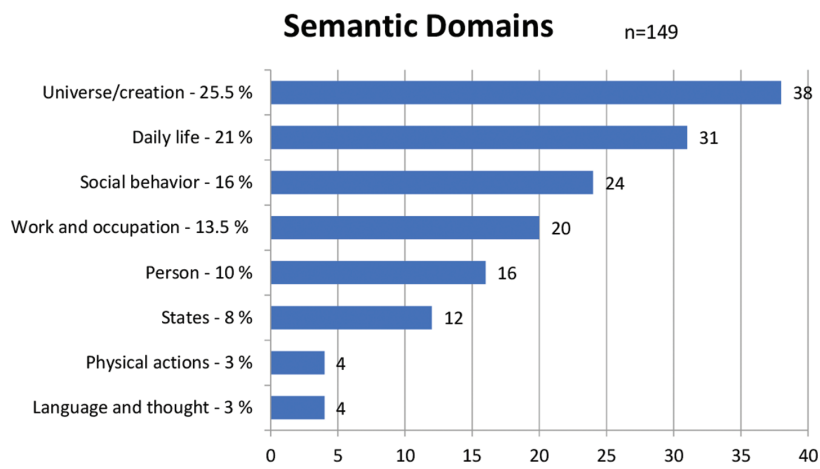

Figure 1: Distribution of the lexicon in semantic domains.

\subsection{Basic vocabulary}

With respect to the list of 100 basic vocabulary items compiled by Swadesh (1971), 16\% (24/149) of the words can be classified as basic vocabulary, that is, not culture-specific words that exist in individual languages:

1. acrepú 'hand'

2. aiuca 'many'

3. alume 'man'

4. andambí 'woman'

5. anduro 'fire'

6. congembo 'die, dead'

7. copequera 'sleep' 
8. cuata 'take'

9. maravir 'earth'

10. mbambe 'cold'

11. mbungururú 'star'

12. obingá 'horn'

13. ochito 'meat'

14. ombera 'rain'

15. omboá 'dog'

16. omenhá 'water'

17. omerá 'tongue'

18. omindes 'I' PRON 1SG

19. ongira 'path'

20. onjerê 'hair'

21. oquepá 'bone'

22. ossenhê 'moon'

23. ovê 'you' PRON 2SG

24. ucumbi 'sun'

25. uoneme 'big'

Although the basic vocabulary is normally not borrowed lexicon, convincing African etymologies have been identified for 22 of the 24 items that belong to the core vocabulary. These lexical items are distributed in seven of the eight semantic domains: universe and creation, person, social behavior, daily life, work and occupation, physical actions, and states. For acrepú, the etymology was not identified, and for maravir the etymology given by Simões (2014: 123) was not considered convincing (oluali, olwili, meaning Planet Earth). All these lexical items (or items with similar forms and meanings) have been attested in other Afro-Brazilian communities.

\subsection{Specific mining vocabulary}

The words that may be related to specific mining activities show similar results if compared to the basic vocabulary: a total of 18\% (27/149), among which 16 have been identified as being of possible African origin. This result is not surprising as the expertise of Africans was important in the mines, and some mining techniques, such as the use of wooden mining bowls, may have been of West African origin (Boxer 1964: 184; Costa 2007: 252). Available descriptions of mining activities in Minas Gerais during the eighteenth and nineteenth century were consulted in order to identify the vocabulary that could be associated with such activities as panning for gold and diamonds, for example: 
The original process of washing and panning for gold was of the simplest. The sole instrument required was the bateia, a large swallow, cone-shaped basin, ${ }^{5}$ made of wood or metal, which the miner held with both hands. The gravelly subsoil mixed with quartz (cascalho) which contained the gold particles was placed in the bateia with a quantity of water just sufficient to cover it. [...] The cascalho was not usually on the surface of the soil, but at varying depths below a layer of sand, earth or clay. (Boxer 1964: 38)

On the heap of cascalhão, at equal distances, are placed three high chairs for the officers or overseers. After they are seated, the negroes enter the troughs, each provided with a rake of a peculiar form and short handle with which he rakes into the trough about fifty or eighty pounds weight of cascalhão. The water being then let in upon it, the cascalhão is spread abroad and continually raked up to the head of the trough, so as to be kept in constant motion. [...] When a negro finds one [diamond], he immediately stands upright and claps his hands, then extends them holding the gem between his fore-finger and thumb; an overseer receives it from him, and deposits it in a gamella or bowl suspended from the center of the structure, half full of water. (Mawe 1812: 223-224)

There are also descriptions of mining activities and the vocabulary used to describe it in dictionaries elsewhere. Two examples are given here from the U.S.:

There are two ways to mine - by hand or by machine. The old hardrock miners (now nearly extinct) were either single jackers or double jackers. The first held his own steel in one hand and hammered with the other. In double jacking, one man held the jack while the other hammered. (Moore 1926: 87)

[...] mud, the call for a driller to indicate that the water poured into the drill hole has now formed mud and that the hammering on the drill should stop [...]. (Davidson 1929: 146)

The following terms were identified as being related to mining activities:
1. Angana 'boss' (overseer?)
2. Arapossé-arapossí 'rest'
3. Arengá 'task'
4. Barundo 'boss' (overseer?)
5. Comboêro 'ditch'
6. Curimã 'work'
7. Imbanda 'boss' (overseer?)
8. Jambá 'gold'
9. Jombô 'black mud'
10. Lamba 'hard work'

11. Maravir 'earth'

12. mbembo 'boss, white man' (overseer?)

13. Mbungururú 'star' (meaning precious stone?)

14. Ndimba 'singer' (of vissungos?)

5 Bold was added by me to indicate lexical items found in the studied vocabulary. 
15. Njeque 'bag' (used by stone dealers)

16. Ongá 'bar for levering'

17. Onjundo 'hammer' (for mining?)

18 Onumuquacho 'work mate'

19. Orongoia 'diamond'

20. Oropungo 'mining bowl'

21. Orovanga 'cotton cloth' (mining filter?)

22. Orumbá 'cone-shaped basin'

23. Otatariangue 'boss' (overseer?)

24. Ovicaiá 'gravel, quartz'

25. Rubudú 'mill' (for mining?)

26. Ungundo 'dust'

27. Vissungo 'work song'

The mining vocabulary is found in two semantic domains: "work and occupation" and "universe and creation". The lexical items 'gold', 'diamond', 'black mud', 'earth', 'gravel', and 'dust' were classified as universe/creation in Figure 1. With the addition of these words, the domain of work/occupation represents almost a fifth (18\%) of the total vocabulary (and the domain of universe/creation decreases to $21 \%$ ).

Convincing etymologies were not found in the consulted dictionaries for the following items: arapossé-arapossí, jambá, jombô, maravir, ongá, orongoia, oropungo, orovanga, orumbá, ovicaiá, rubudú. Of these, jambá is the only word that has been attested in other sources; Vogt and Fry (1996) registered this item in the nearby community of Milho Verde with the meaning of 'diamond', and Simões (2014) proposes a Bantu etymology based on the word 'elephant'. However, the etymon was discarded in this study since its relation to gold was not explained (maybe through the value of ivory as compared to gold). This means that convincing possible etyma have not yet been identified for 11 of the words related to mining activities.

Unexpectedly, while 16 items of this group were also found in other AfroBrazilian communities with similar or related meanings; 11 items were not found in other sources with the same meaning (arapossé-arapossí, arengá, barundo, comboêro, jombô, ndimba, onjundo, oropungo, orumbá, ovicaiá, rubudú), or were only attested in nearby communities by Simões (2014), indicating that their use might be restricted to a few communities in the mining district. This indication is reinforced by a study of the vocabulary of smallscale diamond mining in the adjacent Brazilian state of Goiás, which does not include any of the items registered by Machado Filho (1943) in São João da Chapada (Jerônimo 2014). 


\subsection{The African-derived lexicon}

Among the 17 languages examined in Bartens and Baker (2012), the average proportion of nouns in the African-derived lexicon is $74 \%$. The results of the present study for the words of proposed African origin are: 85\% (105/124) nouns, $8 \%$ (10/124) verbs, 7\% (9/124) adjectives and adverbs, and 2\% (2/124) pronouns.

Table 1 shows that vocabulary of shared possible origin represents $61 \%$ of all African-derived nouns, $80 \%$ of the African-derived verbs, and $33.5 \%$ of the African-derived adjectives. As $55 \%$ of adjectives and adverbs, and both pronouns, were found only in Umbundu dictionaries, and the etymologies reported as shared include Umbundu, this language stands out, although less than 50\% of the verbs and nouns were identified only as Umbundu.

Table 1: Distribution of the African-derived lexicon according to origin and word class.

\begin{tabular}{|c|c|c|c|}
\hline $\begin{array}{l}\text { Word } \\
\text { class }^{i}\end{array}$ & $\begin{array}{l}\text { African origin } \\
83 \%(124 / 149)\end{array}$ & Etymologies ${ }^{\mathrm{ii}}$ & Examples \\
\hline noun & $85 \%(105 / 124)$ & $\begin{array}{l}61 \%(64 / 105) \text { Shared between Umbundu and at } \\
\text { least one more language (Kikongo, Kimbundu) } \\
29.5 \%(31 / 105) \text { Umbundu } \\
9.5 \%(10 / 105) \text { Kimbundu and Kikongo }\end{array}$ & $\begin{array}{l}\text { calunga 'sea' } \\
\text { ombera 'rain' } \\
\text { omenhá 'water' } \\
\text { apuco 'rat' }\end{array}$ \\
\hline verb & $8 \%(10 / 124)$ & $\begin{array}{l}80 \%(8 / 10) \text { Shared between Umbundu and at } \\
\text { least one more language (Kikongo, Kimbundu) } \\
20 \%(2 / 10) \text { Umbundu }\end{array}$ & $\begin{array}{l}\text { cuendê, oenda } \\
\text { 'go in' } \\
\text { pupiá 'talk' }\end{array}$ \\
\hline $\mathrm{adj} / \mathrm{adv}$ & $7 \%(9 / 124)$ & $\begin{array}{l}55.5 \%(5 / 9) \text { Umbundu } \\
33.5 \%(3 / 9) \text { Shared between Umbundu and at } \\
\text { least one more language (Kikongo, Kimbundu) } \\
11 \%(1 / 10) \text { Kimbundu }\end{array}$ & $\begin{array}{l}\text { aiuca 'much' } \\
\text { uoneme 'big' } \\
\text { cambrocotó, } \\
\text { insulting term }\end{array}$ \\
\hline pronouns & $2 \%(2 / 124)$ & $100 \%$ Umbundu $(2 / 2)$ & $\begin{array}{l}\text { ovê 'You', } \\
\text { omindes 'l' }\end{array}$ \\
\hline
\end{tabular}

i Two verbs are also used as nouns and were counted both as verbs and nouns (arirê and congembo), but not added to the total number of words.

ii See Appendix for list of possibly African-derived words with dubious etymologies.

The relatively high proportions of Umbundu etyma among adjectives and adverbs together with the two pronouns indicate that this language may have played a more dominant role than other African languages when those languages were still spoken in the region. Baker's hypothesis is that groups with higher demographic weight in the earliest periods of colonization contribute more words in general and more lexical items that belong to word classes other 
than noun in particular (Baker 2012: 283). In sum: among the words of African origins there are mostly nouns, as expected, and Umbundu stands out in all word classes.

Table 2 shows that the African-derived vocabulary is distributed among different semantic domains and is not restricted to specific activities associated with African cultures or slavery. The results are similar to the numbers in Figure 1 for the whole vocabulary: a majority of the lexical items are in the domain of universe/creation, and the lowest number is in language/thought.

Table 2: Distribution of the African-derived lexicon according to semantic domains.

\begin{tabular}{lll}
\hline Semantic domains of African-derived lexicon & $\begin{array}{l}\text { Distribution } \\
\text { (n= 124) }\end{array}$ & Examples \\
\hline Universe/creation & $24 \%(30)$ & ucumbi 'sun' \\
Daily life & $23 \%(29)$ & onjó 'house' \\
Social behavior & $16 \%(20)$ & vissungo 'song' \\
Person & $12 \%(15)$ & alume 'man' \\
Work and occupation & $11 \%(14)$ & curima 'work' \\
States & $9 \%(11)$ & otequê 'day' \\
Physical actions & $2 \%(3)$ & cuata 'take' \\
Language and thought & $2 \%(2)$ & pupiá ondaca 'speak the tongue'
\end{tabular}

Summing up, $17 \%$ of all the words were identified as core lexicon, and $18 \%$ as being related to work/occupation or mining activities. At the same time, almost $50 \%$ of the African-derived lexical items belong to the semantic domains universe/creation and domestic/daily life.

\subsection{Etymologies and demography}

With the gold rush, enslaved Africans replaced indigenous labor force at the end of the seventeenth century, among other reasons, because Africans had experience with gold extraction. Consequently, Minas Gerais became the region with the largest contingent of slaves in Brazil (Costa 2007: 252).

Apart from Africans and their descendants, "many 'poor whites' engaged in prospecting and mining on their own", and there were also numerous Indigenous slaves (Boxer 1964: 167, 184). In the eighteenth century, most immigrants from Portugal living in Minas were young unmarried men from the regions of Minho and Douro (Boxer 1964: 163-164). This is probably why the 
vocabulary includes words of African origin, but also words with no relation to Africa.

According to Costa (2007: 252), there were 120,000 inhabitants in Minas Gerais in 1720. Slaves from West Africa were the most numerous between 1714 and 1740, "closely followed by slaves from Angola [probably Kimbundu speakers] and Benguela [probably Umbundu speakers]” (Boxer 1964: 175). Although West Africans were the majority in Minas Gerais during the eighteenth century, Brazilian-born slaves and speakers of Bantu languages from West Central Africa dominated in the nineteenth century (Luna 1980). Unfortunately, we lack detailed historical studies about the population of the municipality of Diamantina, but for the region of Minas Gerais, this means that speakers of Umbundu were present, as well as speakers of other Bantu languages. In 1767, there were 126,603 slaves in the captaincy, a number that represented $60.7 \%$ of its total population (Resende 2006: no page).

From a more local perspective, we know that in 1830, slaves represented $36 \%$ of the total population in the traditional mining centers in Minas Gerais (Luna and Klein 2004: 10), and in Diamantina there were as many as 7,800 slaves out of 15,200 inhabitants in 1853 (Costa 1998: 104). This means that half of the population was still composed of slaves three years after the legal slave trade had ended in 1850. The death rate of slaves was high, and their reproduction rate low (Boxer 1964: 175), probably because they lived under unfavorable conditions imposed by the slave system in the mining region. Furthermore, in Diamantina, African-born slaves predominated longer than elsewhere in Minas due to the activities of the royal diamond monopoly (Bergad 1999: 129).

In rural communities in this district, such as São João da Chapada, is it likely that newly imported African slaves who spoke Bantu languages had only limited access to Portuguese spoken as a first language unless they were house slaves. After the abolition of slavery in 1888, some of the former mining slaves probably ended up living in communities similar to the six maroon communities (called quilombos, a term with Bantu origins) situated around São João da Chapada and described by Machado Filho (1943: 54-56). At that time, a class society in which Africans and their descendants were marginalized was established - especially since there were no measures taken to integrate former slaves into Brazilian society (Álvarez López 2004: 12-13). As a result of those colonial and postcolonial social structures, there are today approximately 3,000 more or less marginalized communities throughout Brazil (many of them in Minas Gerais) that can be classified as maroon, or quilombolas, in accordance with the Presidential Decree 4887 from November 20, 2003. However, runaway slaves did not found most such communities, as many of them emerged only after 1888, when freed slaves did not have anywhere to go. Several Afro-Brazilian 
varieties have emerged in similar communities (see, for example, Lucchesi et al. 2009; Vogt and Fry 1996).

\subsection{Comparing with mining languages and other Afro-Brazilian varieties}

As has been the case in researching other mining communities in different parts of the world, in Minas Gerais we are dealing with work songs and an innovative, specialized vocabulary related to small-scale mining technologies in multilingual, male-dominated communities where people of various origins gather to exploit minerals (see Muysken this volume). As expected, based on research on mining languages, the vocabulary relies on the languages originally used by members of the work force.

However, if we look at Afro-Brazilian multilingual and male-dominated settings where mining is not part of everyday life, we will also find slaves, work songs, and small-scale technologies in everyday life. Sugar-cane plantations may serve as an example in this regard. At the same time, Afro-Brazilian communities in the State of Minas Gerais have been studied because of their use of "special languages" with vocabularies similar to the one registered by Machado Filho: Língua do Negro da Costa in Tabatinga (175 words, Queiroz 1998) and Calunga in Patrocínio (305 words, Byrd [2012]). These varieties are used as secret in-group codes in which the specific vocabulary replaces part of the lexicon in in-group conversations in Portuguese.

In the case of São João da Chapada, Machado Filho (1943) affirms that a "creole language" was spoken, but his data does not provide more than a number of songs and a glossary. In light of the research that has been accomplished in pidgin and creoles studies from the 1980s onward, this glossary falls short of the linguistic evidence necessary for proving the existence of a creole language. His statement can be related to the debates on the origins of innovative features in Brazilian Portuguese, a discussion that has been largely marked by the polarization involving mainly two hypotheses. The first is the so-called "hypothesis of internal drift", according to which changes attested in Brazil are solely derived from a natural evolution of European Portuguese (Naro and Scherre 2007). The second is the "contact hypothesis", in which creolization and the role of African languages have received special attention, given that Africans and their descendants came to compose a significant part of the Brazilian population between the seventeenth and nineteenth centuries (Lucchesi et al. 2009). This issue is still the topic of an ongoing debate, but during the last 30 years a significant number of studies have supported the 
contact hypothesis, both in empirical studies on varieties defined as "AfroBrazilian” and in emerging studies of Portuguese in Africa.

One of the studies on Afro-Brazilian varieties focuses on the community of Cafundó, situated in the neighboring state of São Paulo. The variety called Cupópia can be compared to the dialect of São João da Chapada, and has probably survived until today because of its prevailing function as a secret ingroup code, or marker of social distance with out-groups, used in everyday life (160 words, see Álvarez López and Jon-And [2017], Vogt and Fry [1996]). The results of the lexical study of Cupópia are similar to those obtained in the analysis of the dialect of São João da Chapada. The basic vocabulary of Cupópia represents $28 \%$ (compared to $17 \%$ in São João da Chapada), and the African-derived words $71 \%$ (compared to $83 \%$ ), and, out of these, there are $83 \%$ nouns (compared to 85\%), 11\% verbs (compared to $8 \%$ ), $7 \%$ adjectives and adverbs (compared to $7 \%$ ), and $1 \%$ other (one greeting compared to $2 \%$, represented by two pronouns). Regarding the distribution in semantic domains, it is similar in the two vocabularies, as shown in Table 3; the differences are mainly that Cupópia has fewer words in the domains "universe and creation" and "social behavior" and more words classified under "person".

Table 3: Distribution of the African-derived lexicon according to semantic domains in Cupópia and the dialect of São João da Chapada.

\begin{tabular}{lrr}
\hline $\begin{array}{l}\text { Semantic domains of African-derived } \\
\text { lexicon }\end{array}$ & $\begin{array}{r}\text { São João da } \\
\text { Chapada }\end{array}$ & Cupópia \\
\hline Universe/creation & $24 \%$ & $16 \%$ \\
Daily life & $23 \%$ & $27 \%$ \\
Social behavior & $16 \%$ & $8 \%$ \\
Person & $12 \%$ & $24 \%$ \\
Work and occupation & $11 \%$ & $9 \%$ \\
States & $9 \%$ & $6 \%$ \\
Physical actions & $2 \%$ & $3.5 \%$ \\
Language and thought & $2 \%$ & $5.5 \%$ \\
\hline
\end{tabular}

For Cupópia, the distribution in semantic domains was tentatively explained by the fact that it has the function of a secret code used to signal distance between speakers and out-groups, and is used in everyday life by members of in-groups as an identity marker (Álvarez López and Jon-And 2017). They probably needed basic words to use Cupópia as a secret code in everyday life. This could also be the case for the dialect of São João da Chapada, since historical sources reveal that mining slaves may have needed such a code to perform daily activities. 
Etymologically, the results show that approximately half of the nouns and verbs were of shared origin in both vocabularies, but whereas Kimbundu dominated in Cupópia for adjectives and adverbs, Umbundu dominated in São João da Chapada. In the case of Cupópia, the detailed study of the genealogies in the community by Robert Slenes (Vogt and Fry 1996: Ch. 2) showed a higher demographic weight historically for speakers of Kimbundu. Unfortunately, we still lack detailed information concerning the origins of the African population in São João da Chapada and its surroundings.

\subsection{Secrecy and strategies of resistance in the mining region}

In sociocultural and historical settings similar to the one described by Machado Filho, the political protest in work songs and the value of secret codes as strategies of resistance have been emphasized:

[...] unlike the songs of lumberjacks and other occupational groups in the Midwest, coalmining songs represent mass protest; there is a growing passion for unionism that doesn't show up in many of the songs of other occupational groups. Miners' songs tell of greedy bosses, long hours, dangers of work, poor working conditions and disasters. In addition, miners lived with their families close to the shafts, so miners' songs reveal a domestic life that doesn't appear in songs of lumberjacks and other occupational groups. (Baker 2015: 794)

In Minas Gerais, the work songs, or vissungos, were performed to accompany different phases of the mining work: in the morning, during lunch break, in the afternoon, when the boss was arriving at the field, to pray the Lord's Prayer, and to carry the dead to the closest cemetery (Machado Filho 1943: 61-62). There were also special songs addressed to "fine" individuals who arrived at the mining site, demanding that they be offered something.

Nevertheless, as society has changed, the social functions of the mining songs have also changed. Nowadays, the vissungos are not necessarily related to mining work, but they represent a cultural heritage, and sometimes resistance, in the same way as African-American work songs in the U.S. or coal-mining songs in Europe do. We also know that several vissungo masters were rivals; they had their own choirs and did not teach their songs to outsiders. According to Andrarde (2012: 338-339), vissungos can be understood as a secret language in the remains of maroon communities. They embody the transmission of knowledge through a whole set of expressive oral resources.

A concrete example of secrecy and resistance in this mining sociocultural context is the vissungo in which a son tells his father that he found a diamond, 
and the father tells him to hide it in the gravel and be quiet (Machado Filho 1943: 75). With the use of the specific vocabulary, the song becomes unintelligible for an overseer who speaks only Portuguese.

In addition, travelers who visited Brazil during the nineteenth century comment on the problem of slaves stealing gold and diamonds, maybe in order to buy their freedom. Mawe (1812: 223-224) affirms that "[m]any precautions are taken to prevent the negroes from embezzling diamonds". Furthermore, in his study of the Golden Age of Brazil, Boxer (1964: 217) states: "the authorities were convinced that the mulatas and Negresses who sold food and drinks to the miners were chief intermediaries in the smuggling game”, which means that this did not only happen at an individual level, but in a more or less organized way. Mining slaves and their allies might therefore have needed a secret code in order to be able to keep some of the minerals that they worked so hard to find for someone else's profit. Another illustrative example of organized resistance in the area is the Serro slave rebellion in 1864, in which more than four hundred mining slaves gathered, as well as slaves from the farms and the cities of Serro and Diamantina, in order to obtain their freedom with the support from maroon communities and black freedmen (Mota 2006).

\section{Final remarks}

In light of earlier research, the songs, words, and expressions registered by Machado Filho (1943) are possibly the vestiges of a lexically-driven in group code, mainly based on the manipulation of part of a differentiated vocabulary (of which 149 remaining words were registered in 1929) used primarily in mining settings.

The etymological analysis and the distributions of words of different origins in different word classes reveals that Umbundu maintained a high status in the area, but there is not enough historical and demographic data concerning the community of São João da Chapada and its surroundings to support this claim.

As for the distribution of the lexical items in different semantic fields, the results show that approximately one fifth of all the words can be identified as core lexicon, and one fifth might be related to work/occupation or mining activities. At the same time, almost half of the lexical items belong to the semantic domains universe/creation and domestic/daily life. Therefore, this variety is not limited to mining activities, but can be used in everyday life, possibly as a secret code. 
There is an aspect of resistance and secrecy that most communities founded by descendants of enslaved Africans in the Americas seem to share in one way or another. That aspect generates the need for strategies of resistance and secrecy, which can explain the emergence of a specific African-derived ingroup code among enslaved Africans and their descendants, as well as justify the survival of fragments of such a code even today in the surroundings of São João da Chapada (Nascimento 2003; Simões 2014).

\section{Appendix}

\section{List of analyzed words}

The sources for the etymologies are discussed in Section 3.3 of the article. For words that were not found in glossaries or dictionaries, the reference of the source is indicated in the fourth column.

\begin{tabular}{|c|c|c|c|}
\hline Lexical item & Gloss & Possible etym & $\begin{array}{l}\text { Possible source } \\
\text { language }\end{array}$ \\
\hline 1. Acrepú & Hand & - & - \\
\hline 2. Aiuca & Many & Yuka 'be full' & Umb \\
\hline 3. Alume & Man & $\begin{array}{l}\text { Ulume 'man', } \\
\text { mulume 'husband' }\end{array}$ & Umb, Kimb \\
\hline 4. Andambí & Woman & $\begin{array}{l}\text { Ondambi 'a good man or } \\
\text { woman', } \\
\text { ndumbu 'prostitute' }\end{array}$ & Umb, Kimb, Kik \\
\hline 5. Anduro (ondara) & Fire & Ondalu, ndalu 'fire' & Umb, Kik \\
\hline 6. Angana & $\begin{array}{l}\text { Boss, } \\
\text { overseer }\end{array}$ & Ngana 'master' & $\begin{array}{l}\text { Kimb (possibly } \\
\text { Umb, Simões } \\
\text { 2014) }\end{array}$ \\
\hline 7. Angana-iangue & Boss, master & Ngana 'master' & $\begin{array}{l}\text { Kimb (possibly } \\
\text { Umb, Simões } \\
\text { 2014) }\end{array}$ \\
\hline $\begin{array}{l}\text { 8. Angana-nzambi } \\
\text { (zambiopungo; anzambe; } \\
\text { angana-nzambi-opungo; } \\
\text { angananzambí; } \\
\text { ganazambi; anzambê; } \\
\text { angazambí; anzambí; } \\
\text { anganaiovê; nganazambi; } \\
\text { ganazambe) }\end{array}$ & God, saint & $\begin{array}{l}\text { Ngana, Ngana-Nzambi Nzambi- } \\
\text { pungo, Nzambi 'God' }\end{array}$ & Umb, Kimb, Kik \\
\hline
\end{tabular}


(continued)

\begin{tabular}{|c|c|c|c|}
\hline 9. Anguê & Jaguar & Ongwe 'ounce' (animal) & Umb \\
\hline 10. Aquenjê & Boy & Okwenju 'boy', ukwenje 'youth' & Umb \\
\hline 11. Araposse-arapossí & Rest & - & - \\
\hline 12. Arengá & Task, job & Linga 'do', Mulenga 'plowing' & Umb, Kimb \\
\hline 13. Arirê & To tell, song & Lila 'cry', dila 'cry, whine' & Umb, Kimb, Kik \\
\hline 14. Atanhara & High & $\begin{array}{l}\text { Utanya 'sunshine' (as when the } \\
\text { sun is high/rises, see the } \\
\text { example with translation by } \\
\text { Machado Filho: Atanhara, } \\
\text { ucumbi u atundá 'woman the } \\
\text { sun is high') }\end{array}$ & Umb \\
\hline 15. Atundá & High & $\begin{array}{l}\text { Tunda 'depart' (as when the } \\
\text { sun is high/rises, see the } \\
\text { example with translation by } \\
\text { Machado Filho: Atanhara, } \\
\text { ucumbi u atundá 'woman the } \\
\text { sun is high') }\end{array}$ & Umb, Kimb \\
\hline 16. Barundo & $\begin{array}{l}\text { Boss, } \\
\text { overseer }\end{array}$ & $\begin{array}{l}\text { Umbalu 'brave man', Mbalu } \\
\text { 'brave' }\end{array}$ & Umb, Kimb \\
\hline 17. Cachupá & To smoke & Sipa, xipa 'to smoke' & Umb, Kimb \\
\hline 18. Calunga & Sea & $\begin{array}{l}\text { Okalunga 'spirit world, ocean', } \\
\text { Kalunga 'sea' }\end{array}$ & Umb, Kimb, Kik \\
\hline 19. Cambambe & Deer & Ombambi, mbambi 'deer' & Umb, Kimb \\
\hline 20. Cambrocotó & $\begin{array}{l}\text { Injurious } \\
\text { term }\end{array}$ & Ximbolokoto 'wart'? & Kimb \\
\hline 21. Camundá & Hill & Omuda 'mountain' & Umb \\
\hline 22. Camuquengue & Boy & $\begin{array}{l}\text { Ukwenje 'youth', mukuenze } \\
\text { 'athlete' }\end{array}$ & Umb, Kimb \\
\hline 23. Cananenecô & $\begin{array}{l}\text { Injurious } \\
\text { term }\end{array}$ & Kiwaneneko 'I am not great' & Kik \\
\hline 24. Candamburo & Rooster & $\begin{array}{l}\text { Ekondombolo, kolombolo, } \\
\text { ekolombolo 'rooster', }\end{array}$ & Umb, Kimb, Kik \\
\hline 25. Candimba & Rabbit & Ondimba, ndimba 'rabbit' & Umb, Kimb \\
\hline 26. Candonga & Intrigue & $\begin{array}{l}\text { Ndonga 'group gathering' } \\
\text { (where opinions and } \\
\text { judgements are given) }\end{array}$ & Kimb \\
\hline 27. Cangúia & $\begin{array}{l}\text { Injurious } \\
\text { term }\end{array}$ & - & - \\
\hline 28. Canguru (onguro) & Pig & Ongulu, ngulu 'pig' & Umb, Kimb, Kik \\
\hline 29. Canjira-canjerê & To dance & Kina, cina 'to dance' & Umb, Kimb \\
\hline 30. Canjonjo & Kolibri & $\begin{array}{l}\text { Kánzonzo 'blue bird', } \\
\text { Onjonjo 'kolibri' }\end{array}$ & $\begin{array}{l}\text { Umb, Kimb } \\
\text { (Simões 2014) }\end{array}$ \\
\hline
\end{tabular}


(continued)

31. Capungo

32. Caquí

33. Carimbamba

34. Carumbi

35. Catiça

36. Catita

37. Caveia

38. Caxicovera

39. Combaro

40. Comboêro

41. Congá

42. Congembo

43. Copequera

44. Corofeca

45. Covicanda

46. Cuata

47. Cuendê

48. Curiacuca

49. Curiandamba

50. Curimã

51. Imbanda
Bad person Kapiangu 'thief'

Umb

Valiant,

sorcerer

Owl

Inlander,

nackcountry

Help

Small, little

Interjection

(what's up?)

Illness

Inhabited

place

Ditch

Bottle

Die, dead

Kasi 'be' + vela 'sick' Umb prefix ku?), mbala, buala

'village' 'below', Mbuelo 'valley'
Ombala 'capital' (+ locative Umb, Kimb, Kik

Ombuelu 'lowland', K'ombwelu Umb, Kimb

Ukonga 'longneck bottle’ Umb (Simões

2014)

Umb, Kimb

(Simões 2014;

Angenot et al.

1974)

Umb

Pekela 'sleep' (+ infinitive

prefix $k u$ )

Bad (person) -

Write, talk

Ukanda, omukanda, mukanda, nkanda 'letter'

Take, catch Kwata, kuata 'seize'

Go, walk

Enda (+ infinitive prefix $k u$ ), kuenda, okuenda 'go'

Cook

Lia (+ infinitive prefix $k u$ ),

kúdia, diá, kuria 'eat' + kuka,

kuku, 'grandparent', iakuka

'old'

Old person

Ukulu wendamba 'eldest one

present'

Work

Boss,

Lima (+ infinitive prefix $k u$ )

'cultivate', Kurima 'farming'

overseer
Ocimbanda 'doctor', kimbanda 'sorcerer, witch' 
(continued)

\begin{tabular}{|c|c|c|c|}
\hline 52. Injara (anjara) & Hunger & Onjala, nzala 'hunger' & Umb, Kimb, Kik \\
\hline 53. Itaco & Buttocks & Etaku, taku, ma-táku 'butt' & Umb, Kimb, Kik \\
\hline 54. Jambá & Gold & - & - \\
\hline 55. Jambí & Grass & $\begin{array}{l}\text { Onjombia 'young grass', } \\
\text { kandámbia 'herb' }\end{array}$ & Umb, Kimb \\
\hline 56. Jombô & Black mud & - & - \\
\hline 57. Lamba & Hard work & $\begin{array}{l}\text { Dilamba, malamba, elamba } \\
\text { 'disgrace' }\end{array}$ & $\begin{array}{l}\text { Kimb (possibly } \\
\text { Umb, Simões } \\
\text { 2014) }\end{array}$ \\
\hline 58. Масисо & & Kuka, kuku 'grandparent' & Umb, Kimb \\
\hline 59. Manganguera & Low in fat & Ngongonela 'low in fat'? & $\begin{array}{l}\text { Umb (Simões } \\
\text { 2014) }\end{array}$ \\
\hline 60. Manjangue & Sibling & $\begin{array}{l}\text { Manje 'younger brother or } \\
\text { sister' }\end{array}$ & Umb \\
\hline 61. Maravir & Earth & - & - \\
\hline 62. Matombô & Manioc & Mutombo 'manioc' & Kimb \\
\hline 63. Mbambe & Cold & Ombambi, mbambi 'cold' & Umb, Kimb \\
\hline 64. Mbanga & Penis & Mbanga 'testicle' & Kimb, Kik \\
\hline 65. Mbembo & $\begin{array}{l}\text { Boss, white } \\
\text { man, } \\
\text { overseer }\end{array}$ & Ampembe 'white' & Kik \\
\hline 66. Mbungururú & $\begin{array}{l}\text { Star } \\
\text { (precious } \\
\text { stone?) }\end{array}$ & $\begin{array}{l}\text { Olumbungululu, lumbungûlu } \\
\text { 'star' }\end{array}$ & Umb, Kimb \\
\hline 67. Meprá & $\begin{array}{l}\text { Plantation, } \\
\text { vegetable } \\
\text { plot }\end{array}$ & Epia 'field'? & Umb \\
\hline 68. Mossoroca & Hard rain & - & - \\
\hline 69. Ndimba & $\begin{array}{l}\text { Singer (of } \\
\text { mining } \\
\text { songs?) }\end{array}$ & Onjimba, njimbi ‘singer’ & Umb, Kimb \\
\hline 70. Nganga & Priest & $\begin{array}{l}\text { Onganga 'wizard', nganga } \\
\text { 'priest' }\end{array}$ & Umb, Kimb, Kik \\
\hline 71. Ngombe & $0 x$ & Ongombe, ngombe 'ox' & Umb, Kimb, Kik \\
\hline 72. Nguenda & Haste, hurry & $\begin{array}{l}\text { Enda (+ infinitive prefix ku?), } \\
\text { kuenda, okuenda 'go'? }\end{array}$ & Umb, Kimb, Kik \\
\hline 73. Nhorrã & Snake & Onyoha, nhoka, nioka 'snake'? & Umb, Kimb, Kik \\
\hline 74. Njequê & $\begin{array}{l}\text { Bag (used by } \\
\text { stone } \\
\text { dealers) }\end{array}$ & Onjeke, nzeke 'bag' & Umb, Kimb \\
\hline 75. Npuco & Rat & Puku, mpuku 'rat' & Kimb, Kik \\
\hline 76. Obingá & Horn & Ombinga, mbinga 'horn' & Umb, Kimb \\
\hline
\end{tabular}


(continued)

\begin{tabular}{|c|c|c|c|}
\hline 77. Ocaiá & Tobacco & $\begin{array}{l}\text { Ekaya, (di)kanha/(ma)kanha, } \\
\text { káia/(ma)kaia 'tobacco-leaf' }\end{array}$ & Umb, Kimb, Kik \\
\hline 78. Ocará & Coffee & $\begin{array}{l}\text { Ekala, (di)kala/(ma)kala, ekala } \\
\text { 'coal'? }\end{array}$ & Umb, Kimb, Kik \\
\hline 79. Ochito & Meat & Ositu, xitu 'meat' & Umb, Kimb \\
\hline 80. Oenda & $\begin{array}{l}\text { You go, he } \\
\text { goes }\end{array}$ & $\begin{array}{l}\text { Enda (+ infinitive prefix ku?), } \\
\text { kuenda, okuenda 'go' }\end{array}$ & Umb, Kimb, Kik \\
\hline 81. Oique & Brown sugar & Owiki, uíki ‘honey’ & Umb, Kimb \\
\hline 82. Ombera & Rain & Ombela 'rain' & Umb \\
\hline 83. Ombiá & Cigar & $\begin{array}{l}\text { Ombia, ímbia, mbiá 'pot’? ('pot' } \\
\text { used in English for marihuana) }\end{array}$ & Umb, Kimb, Kik \\
\hline 84. Ombingá & Slim & - & - \\
\hline 85. Omboá & Dog & Ombwa, mbua 'dog' & Umb, Kimb, Kik \\
\hline 86. Omenhá & Water & Menha, méia 'water' & Kimb, Kik \\
\hline 87. Omerá & Tongue & Omena 'mouth' & Umb \\
\hline 88. Omindes & I (PRON 1SG) & $\begin{array}{l}\text { Ame ndi 'l' (pronoun and verb } \\
\text { prefix } 1 \mathrm{sg} \text {, as in ame ndi } u \text { - } \\
\text { kòngo 'I am a hunter') }\end{array}$ & $\begin{array}{l}\text { Umb } \\
\text { (Nascimento } \\
1894 \text { Gramática } \\
\text { do Umbundu) }\end{array}$ \\
\hline 89. Omungá & Salt & $\begin{array}{l}\text { Omongwa, móngua/múngua } \\
\text { 'salt' }\end{array}$ & Umb, Kimb \\
\hline 90. Ongá & $\begin{array}{l}\text { Bar for } \\
\text { levering }\end{array}$ & - & - \\
\hline 91. Ongira & Path, road & Onjila, njila, nzila 'road' & Umb, Kimb, Kik \\
\hline 92. Ongoró & Horse, mare & Ongolo, ngolo 'zebra' & Umb, Kimb \\
\hline 93. Oninga & Bad smell & Onine 'dung' & Umb \\
\hline 94. Onjequê & $\begin{array}{l}\text { Maize } \\
\text { porridge }\end{array}$ & Kanjica 'maize porridge' & Kimb \\
\hline 95. Onjerê & Hair & Olonjele 'beard' & Umb \\
\hline 96. Onjó & House & Onjo, inzo, nzo 'house' & Umb, Kimb, Kik \\
\hline 97. Onjundo & $\begin{array}{l}\text { Hammer (for } \\
\text { mining?) }\end{array}$ & $\begin{array}{l}\text { Onjundo, nzundu 'sledge } \\
\text { hammer' }\end{array}$ & Umb, Kimb \\
\hline 98. numuquacho & $\begin{array}{l}\text { Fellow } \\
\text { worker }\end{array}$ & $\begin{array}{l}\text { Omunu 'person', } \\
\text { mona mukuénu 'stepson' }\end{array}$ & $\begin{array}{l}\text { Umb } \\
\text { Kimb }\end{array}$ \\
\hline 99. Oputá & $\begin{array}{l}\text { Type of corn } \\
\text { porridge }\end{array}$ & Iputa 'mush' & Umb \\
\hline 100. Oquepá & Bone & Ekepa 'bone' & Umb \\
\hline 101. Orerá & Fat, grease & Ulela 'oil, grease, fat' & Umb \\
\hline 102. Oringá & Dust & - & - \\
\hline 103. Oronanga & Clothes & Onanga, nanga 'cloth' & Umb, Kimb \\
\hline 104. Oronganga & Soldier & - & - \\
\hline
\end{tabular}


(continued)

\begin{tabular}{|c|c|c|c|}
\hline 105. Oronganje & Spirit & $\begin{array}{l}\text { Onganja 'small gourd' (to drink } \\
\text { from?) }\end{array}$ & $\begin{array}{l}\text { Umb (Simões } \\
\text { 2014) }\end{array}$ \\
\hline 106. Orongoia & Diamond & - & - \\
\hline 107. Oroní & Firewood & Olohwi 'fuel' & Umb \\
\hline 108. Oropungo & Mining bowl & - & - \\
\hline 109. Orossanje & Hen & Osanje, sanji 'fowl' & Umb, Kimb \\
\hline 110. Orossimba & Cat & Olusimba 'leopard' & Umb \\
\hline 111. Orovanga & $\begin{array}{l}\text { Cotton cloth, } \\
\text { baize } \\
\text { (mining } \\
\text { filter?) }\end{array}$ & - & - \\
\hline 112. Orumbá (carumbé) & $\begin{array}{l}\text { Cone- } \\
\text { shaped } \\
\text { basin }\end{array}$ & - & - \\
\hline 113. Ossemá & Cornmeal & Osema 'meal' & Umb \\
\hline 114. Ossenhê & Moon & Osai 'moon' & Umb \\
\hline 115. Otata & Father & Tate, tata, taata '(my) father' & Umb, Kimb, Kik \\
\hline 116. Otatariangue & $\begin{array}{l}\text { Boss, } \\
\text { overseer }\end{array}$ & Otate + lyange 'my father' & $\begin{array}{l}\text { Umb (Simões } \\
\text { 2014) }\end{array}$ \\
\hline 117. Otatariôve & $\begin{array}{l}\text { Injurious } \\
\text { term }\end{array}$ & Otate + lyove 'your father' & $\begin{array}{l}\text { Umb (Simões } \\
\text { 2014) }\end{array}$ \\
\hline 118. Otequê & Day & Eteke 'day' & Umb \\
\hline 119. Otiça & Captivity & - & - \\
\hline 120. Otombô & Manioc flour & Utombo, mutombo 'manioc' & Umb, Kimb \\
\hline 121. Ovê & $\begin{array}{l}\text { You (PRON } \\
2 \mathrm{SG})\end{array}$ & Ove 'thou' & Umb \\
\hline 122. Oviango & Scythe & - & - \\
\hline 123. Ovicaiá & $\begin{array}{l}\text { Gravel, } \\
\text { quatz }\end{array}$ & - & - \\
\hline 124. Oviní & Mother & $\begin{array}{l}\text { Ina (pl. ovaina, his or her) } \\
\text { 'mother' }\end{array}$ & Umb \\
\hline 125. Pamba & Brave man & Pama 'be stout, thick' & Umb \\
\hline 126. Parongo & Sheep & Palanga 'deer' & Kimb \\
\hline 127. Pipoquê & Beans & Ocipoke 'beans' & Umb \\
\hline 128. Pupiá ondaca & $\begin{array}{l}\text { Speak the } \\
\text { Black men's } \\
\text { tongue }\end{array}$ & Popia 'speak', ondaka 'word' & Umb \\
\hline 129. Quimboto & Toad & Ocimboto 'toad', kimboto 'frog' & Umb, Kimb \\
\hline 130. Quimbundo & Black man & $\begin{array}{l}\text { Ocimbundo 'one of the race } \\
\text { which inhabits Oviye. } \\
\text { Ombalundu' }\end{array}$ & Umb, Kimb \\
\hline 131. Quipungo & Hat & Kibunga 'hat' & Kimb \\
\hline
\end{tabular}


(continued)

\begin{tabular}{|c|c|c|c|}
\hline 132. Quissama & Backpack & - & - \\
\hline 133. Quissonde & Red ant & $\begin{array}{l}\text { Ocisonde, kisonde, nsonde } \\
\text { 'army ant' }\end{array}$ & Umb, Kimb, Kik \\
\hline 134. Rio-rio & $\begin{array}{l}\text { Interjection } \\
\text { (hey!) }\end{array}$ & - & - \\
\hline 135. Rubudú & $\begin{array}{l}\text { Mill (for } \\
\text { mining?) }\end{array}$ & - & - \\
\hline 136. Senguê & Bush & Usengue 'forest' & Umb \\
\hline 137. Tiadiambe & Holy day & $\begin{array}{l}\text { Tchya (class prefix) + ndjambi } \\
\text { 'of God' }\end{array}$ & $\begin{array}{l}\text { Umb (Simões } \\
\text { 2014) }\end{array}$ \\
\hline 138. Tiapossoca & $\begin{array}{l}\text { Something } \\
\text { good }\end{array}$ & $\begin{array}{l}\text { Tchya (class prefix) + Posoka } \\
\text { 'be well dressed' }\end{array}$ & $\begin{array}{l}\text { Umb (Simões } \\
\text { 2014) }\end{array}$ \\
\hline 139. Uandá & $\begin{array}{l}\text { Net, } \\
\text { hammock }\end{array}$ & Owanda, Uanda 'sling' & Umb, Kimb, Kik \\
\hline 140. Uanga & $\begin{array}{l}\text { Spell, } \\
\text { witchcraft }\end{array}$ & Owanga, uanga 'charm, fetish' & Umb, Kimb \\
\hline $\begin{array}{l}\text { 141. Ucuêto (vacueto; } \\
\text { acueto) }\end{array}$ & Companion & Mukuetu, nkuetu 'companion' & $\begin{array}{l}\text { Kimb, Kik } \\
\text { (possibly Umb, } \\
\text { Simões 2014) }\end{array}$ \\
\hline 142. Ucumbi & Sun & Ekumbi 'sun' & Umb, kimb \\
\hline 143. Ungundo & Dust & $\begin{array}{l}\text { Ngundu 'wreckage, remain of } \\
\text { buildings, ruins' }\end{array}$ & Kimb \\
\hline 144. Uoneme & Large, big & Nene, uonene, uanene 'large' & Kimb, Kik, Umb \\
\hline 145. Urundungo & Pepper & Olundungu, ndungu 'pepper’ & Umb, Kimb, Kik \\
\hline 146. Vigongo (vicongo) & Pork rinds & Ovikangwa 'lard residual’? & $\begin{array}{l}\text { Umb (Simões } \\
\text { 2014) }\end{array}$ \\
\hline 147. Vinganga & Rice & - & - \\
\hline 148. Vissepa & Straw, hay & Ocisapa 'bough'? & $\begin{array}{l}\text { Umb (Simões } \\
\text { 2014) }\end{array}$ \\
\hline 149. Vissungo & $\begin{array}{l}\text { Work } \\
\text { (mining) } \\
\text { song }\end{array}$ & Ocisungo, nzangu 'song' & Umb, Kik \\
\hline
\end{tabular}

\section{List of possibly African-derived words not found in other Brazilian sources}

The following 35 words not found in the other consulted sources: alume, anganaiangue, aquenjê, arengá, atundá, barundo, cachupá, camundá, cananenecô, canjonjo, capungo, carumbi, caveia, comboêro, corofeca, jambí, jombô, maravir, mbanga, mbungururú, meprá, ocará, ombingá, onjundo, oringá, oropungo, orumbá, otiça, ovicaiá, rubudú, uandá, uanga, vigongo, vinganga, vissepa. 


\section{References}

Álvarez López, Laura. 2004. A Língua de Camões com lemanjá: Forma e Funções da Linguagem do Candomblé. Ph.D. thesis, Stockholm University.

Álvarez López, Laura. 2015. Quem Eram os Minas?: Notas sobre a 'Nação’ Mina no Sul do Brasil e no Prata no Século XIX. In Juanito Avelar \& Laura Álvarez López (eds.), Dinâmicas AfroLatinas: Língua(s) e História(s), 43-63. Frankfurt am Main: Peter Lang.

Álvarez López, Laura \& Anna Jon-And. 2017. Afro-Brazilian Cupópia: Lexical and Morphosyntactic features of a lexically driven in-group code. Journal of Pidgin and Creole Languages 32(1). 75-103.

Andrarde, Rudá Kocubej. 2012. Vissungo e Angú: História e Memórias dos Moinhos de Fubá no Alto Jequitinhonha. Projeto História 44. 331-342.

Angenot, Geralda de Lima, Jean-Pierre Angenot \& Jacky Maniacky. 2013. Glossário de Bantuísmos Brasileiros Presumidos. Revista Eletrônica Língua Viva 2. 1-250.

Angenot, Jean-Pierre, Jean-Pierre Jacquemin, Jacques L. Vinke. 1974. Répertoire des vocables brésiliens d'origine africaine. Lubumbashi: Université du Zaïre, CELTA (Travaux et Recherches 5).

Baker, Philip. 2012. Interpreting the findings. In Angela Bartens \& Philip Baker (eds.), Black through white. African Words and Calques which survived slavery in Creoles and transplanted European languages, 273-286. London/Colombo: Battlebridge.

Baker, Ronald. 2015 [2006]. Midwest. In Simon Bronner (ed.), Encyclopedia of American Folklife, 791-796. Abingdon/New York: Routledge.

Bartens, Angela \& Philip Baker (eds.). 2012. Black through white. African words and calques which survived slavery in Creoles and transplanted European languages. London/ Colombo: Battlebridge.

Bentley, William Holman. 1895. Dictionary and grammar of the Kongo language, as spoken at San Salvador, the Ancient Capital of the Old Kongo Empire, West Africa. Appendix. London: Baptist Missionary Society.

Bergad, Laird. 1999. Slavery and the demographic and economic history of Minas Gerais, Brazil, 1720-1888. New York: Cambridge University Press.

Boxer, Charles Ralph. 1964. The Golden Age of Brazil 1695-1750. Berkeley: University of California Press.

Byrd, Steven. 2012. Calunga and the legacy of an African language in Brazil. Albuquerque: University of New Mexico Press.

Castro, Yeda Pessoa de. 2001. Falares Africanos na Bahia: Um Vocabulário Afro-Brasileiro. Rio de Janeiro: Topbooks.

Castro, Yeda Pessoa de. 2002. A Língua Mina-Jeje no Brasil. Um Falar Africano em Ouro Preto do Século XVIII. Belo Horizonte: Fundação João Pinheiro/Secretaria de Estado da Cultura.

Costa, Emilia Viotti da. 1998. Da Senzala à Colônia, $4^{\mathrm{a}}$ edn. São Paulo: Fundação Editora da Unesp.

Costa, Luciano Rodrigues. 2007. Os Garimpos Clandestinos de Ouro em Minas Gerais e no Brasil: Tradição e mudança. História \& Perspectivas 36-37 (Jan.Dez). 247-279. http://www.seer.ufu.br/index.php/historiaperspectivas/article/viewFile/19115/10266 
Davidson, Levette. 1929. Mining Expressions Used in Colorado. American Speech 5(2). 144-147. Giovanni Júnior, Oswaldo. 2014. A Mineiridade no Modernismo: Aires da Mata Machado e o Registro dos Vissungos. Revista Vozes dos Vales 3(6). 1-31.

Jerônimo, Gabriela Guimarães. 2014. As Garimpas Lexicais e seus Diamantes Linguísticos: Vocabulário do Garimpo de Dimanates no Município de Tres Ranchos-Gioás (1944-1981). Masters' Dissertation, Federal University of Goiás.

Johnston, Harry Hamilton. 1919. A Comparative Study of the Bantu and Semi-Bantu Languages. Oxford: Clarenton Press.

Laman, Karl E. 1936. Dictionnaire kikongo-français avec une carte phonétique décrivant les dialectes les plus importants de la langue dite Kikongo. Bruxelles: Librairie Falk fils, Georges van Campenhout, successeur.

Lucchesi, Dante, Alan Baxter \& Ilza Ribeiro (eds.). 2009. O Português Afro-Brasileiro. Salvador: Edufba.

Luna, Francisco Vidal. 1980. Minas Gerais: Escravos e Senhores. Análise da Estrutura Populacional e Econômica de Alguns Núcleos Mineratórios (1718-1804). Ph.D. thesis, University of São Paulo.

Luna, Francisco Vidal \& Herbert Klein. 2004. Slave economy and society in Minas Gerais and São Paulo. Journal of Latin American Studies 36. 1-28.

Machado Filho, Aires da Mata. 1943. O Negro e o Garimpo em Minas Gerais. Rio de Janeiro: Livraria José Olympio Editora.

Matta, Joaquim Dias Cordeiro da. 1893. Ensaio de Diccionario Kimbúndu-Portuguez. Lisbon: Editora Antonio Maria Pereira.

Mawe, John. 1812. Travels in the Interior of Brazil, Particularly in the Gold and Diamond Districts of that Country, by the Authority of the Prince Regent of Portugal, Including a Voyage to the Rio de la Plata, and an Historical Sketch of the Revolution of Buenos Ayres. London: Longman, Hurst, Rees, Orme, and Brown, Paternoster-Row.

Moore, Helen. 1926. The Lingo of the mining camp. American Speech 2(2). 86-88.

Mota, Isadora Moura. 2006. A Galinha Estava Morta e Pronta e Só Faltava Assar-se: A Revolta Escrava do Serro (Minas Gerais 1864). História Social 12. 35-51.

Naro, Anthony \& Maria Marta Pereira Scherre. 2007. Origens do Português Brasileiro. São Paulo: Parábola.

Nascimento, José Pereira do. 1894. Grammatica do Umbundo ou Língua de Benguella. Lisboa: Imprensa Nacional.

Nascimento, Lúcia Valéria do. 2003. A África no Serro Frio, Vissungos: Uma Prática Social em Extinção. Masters' Dissertation, Universidade Federal de Minas Gerais.

Peixoto, António da Costa. 1944 [1731/1741]. Obra Nova de Língua Geral de Mina, published and presented by Luís Silveira. Lisboa: Agência Geral das Colónias.

Petter, Magarida T. 2013. A Tabatinga revisitada: a manutenção de um léxico de origem africana em Minas Gerais (MG-Brasil). Moderna Språk 213(1). 89-100.

Queiroz, Sonia. 1998. Pé Preto no Barro Branco: A Língua dos Negros da Tabatinga. Belo Horizonte: Editora da UFMG.

Resende, Rodrigo Castro. 2006. As 'Nossas Áfricas': População Escrava e Identidades Africanas nas Minas Setecentistas. Masters' Dissertation, Universidade Federal de Minas Gerais.

Simões, Everton Machado. 2014. África Banta na Região Diamantina: Uma Proposta de Análise Etimológica. Master's dissertation, University of São Paulo. 
Skidmore, Thomas E. 1999. Brazil: Five centuries of change. New York: Oxford University Press.

Swadesh, Morris. 1971. The origin and diversification of language. Edited post mortem by Joel Sherzer. Chicago: Aldine.

Thomason, Sarah \& Terrence Kaufman. 1988. Language contact, creolization, and genetic linguistics. Berkeley/Los Angeles: University of California Press.

Vogt, Carlos \& Peter Fry. 1996. Cafundó - A África no Brasil. Linguagem e sociedade. Campinas: Editora da Unicamp. 